University of Nebraska - Lincoln

DigitalCommons@University of Nebraska - Lincoln

1991

\title{
Habitat Associations and Relative Densities of Rodent Populations in Cultivated Areas of Central Argentina
}

James N. Mills

John Hopkins University

Barbara A. Ellis

John Hopkins University

Kelly T. McKee

United States Army Medical Research Institute of Infectious Diseases

Julio I. Maiztegui

Instituto Nacional de Estudios Sobre Virosis Hemorrdgic

James E. Childs

John Hopkins University, james.childs@yale.edu

Follow this and additional works at: https://digitalcommons.unl.edu/zoonoticspub

Part of the Veterinary Infectious Diseases Commons

Mills, James N.; Ellis, Barbara A.; McKee, Kelly T.; Maiztegui, Julio I.; and Childs, James E., "Habitat Associations and Relative Densities of Rodent Populations in Cultivated Areas of Central Argentina" (1991). Other Publications in Zoonotics and Wildlife Disease. 82.

https://digitalcommons.unl.edu/zoonoticspub/82

This Article is brought to you for free and open access by the Wildlife Disease and Zoonotics at DigitalCommons@University of Nebraska - Lincoln. It has been accepted for inclusion in Other Publications in Zoonotics and Wildlife Disease by an authorized administrator of DigitalCommons@University of Nebraska - Lincoln. 


\title{
HABITAT ASSOCIATIONS AND RELATIVE DENSITIES OF RODENT POPULATIONS IN CULTIVATED AREAS OF CENTRAL ARGENTINA
}

\author{
James N. Mills, Barbara A. Ellis, Kelly T. McKee, \\ Julio I. Maiztegui, and James E. Childs \\ Department of Immunology and Infectious Diseases, Johns Hopkins University, \\ Baltimore, MD 21205 (JNM, BAE, JEC) \\ Medical Division, United States Army Medical Research Institute of Infectious Diseases, \\ Fort Detrick, Frederick, MD 21701 (KTM) \\ Instituto Nacional de Estudios Sobre Virosis Hemorrágicas, C.C. 195, \\ 2700 Pergamino (Buenos Aires), Argentina (JIM)
}

\begin{abstract}
Small mammals were livetrapped during 12 months in crop fields and weedy borders at 18 sites in central Argentina. A total of 1,652 mammals of 14 species was captured during 33,060 trap-nights. Six species of rodents comprised $>95 \%$ of captures. Periodically disturbed fields of crops were dominated by Calomys musculinus and C. laucha, and to a lesser extent Mus musculus. A second group composed of Akodon azarae, Bolomys obscurus, and Oligoryzomys flavescens primarily inhabited the more stable, weedy borders of cultivated fields. Peaks in relative densities of C. musculinus, C. laucha, and M. musculus were observed in summer and early autumn, and populations declined to low numbers in winter, following harvest. In contrast, maxima for A. azarae, B. obscurus, and $O$. flavescens were in late autumn and early winter, and numbers never declined to low values seen for the other species. These characteristic differences in habitat associations and relative densities of pampas rodents may reflect colonizing potential, as both Calomys and Mus potentially are highly opportunistic genera.
\end{abstract}

The common rodent species of the central Argentine pampas show distinct habitat associations, interspecific interactions, and reproductive rates. Akodon azarae and Bolomys obscurus, for example, are found predominantly in more stable linear habitats (fencerows, roadsides, and railroad rights-of-way), and may be behaviorally dominant over the two species of Calomys (de Villafañe et al., 1977; Kravetz, 1977). Species of Calomys frequently are numerically dominant in cultivated fields and have been described as better colonizers than Akodon and Bolomys by virtue of larger litter size, reproduction at younger age, and high frequency of postpartum estrus (de Villafañe et al., 1977). Interspecific interactions and seasonal changes in suitability of habitats may result in different patterns in population processes among rodent species that inhabit the pampas.

Four of $\geq 10$ species of rodents present (C. musculinus, C. laucha, A. azarae, and Mus musculus) were implicated as hosts of Junin virus, etiologic agent of Argentine hemorrhagic fever (Sabattini and Contigiani, 1982; Sabattini et al., 1977), a serious viral disease infecting humans in a small area in southern Santa Fe and Córdoba, and northern Buenos Aires and La Pampa provinces. As a consequence, many ecological studies during the past 30 years were directed toward understanding and controlling the rodent reservoir of this disease. In crop fields, lower densities of rodents were found in soybeans than in corn (Busch et al., 1984; Maiztegui et al., 1986), suggesting that reducing cultivation of corn in favor of soybean production would decrease populations of rodents. Further, as a correlation was observed between high densities of rodents in corn fields and high incidence of Argentine hemorrhagic fever (Instituto de Virología de Córdoba, 1966; Sabattini and Maiztegui, 1970), this change of cultivation practices also may lead to lower incidence of the disease (Busch et al., 1984).

A model of the community dynamics of rodents in agroecosystems of the pampas was developed (de Villafañe et al., 1977; Kravetz, 1977). The model contains agricultural alterations of the habitat, predation, and interspecific interactions, and was used to predict that maintenance of permanent bands of stable habitat will result in greater populations of Akodon and Bolomys. 
The greater competitive pressure would, in turn, reduce populations of the principle carriers of Junin virus (Calomys sp.), and concurrently, the incidence of Argentine hemorrhagic fever.

Most previous studies of rodent populations in the pampas were restricted to short periods during seasons of peak rodent densities (de Villafañe et al., 1973, 1988; Lord et al., 1971; Polop et al., 1982), or limited to one habitat type (Crespo, 1966; Crespo et al., 1970; de Villafañe et al., 1973, 1988; Kravetz et al., 1975; Polop et al., 1982), and all of these investigators apparently used only one size of trap to sample the mammalian fauna. We initiated an intensive and extensive trapping protocol in southern Santa $\mathrm{Fe}$ and northern Buenos Aires provinces to sample mammals in diverse habitats during an extended period. Herein, we describe the results of 12 months of small-mammal trapping and discuss the observed patterns of habitat use and species abundance. These results are interpreted in light of recent ecological hypotheses and models regarding the dynamics of rodent communities in cultivated regions of the pampas.

\section{Study Area AND Methods}

Trapping was conducted at 18 farm sites in 13 communities across a broad area of southern Santa Fe and northern Buenos Aires provinces, Argentina $\left(32-33^{\circ} \mathrm{S}, 60^{\circ} \mathrm{W}\right)$. The elevation of the 13 communities ranges from 50 to $100 \mathrm{~m}$ above mean sea level. This area of the pampas is a fertile plain dedicated to extensive agriculture and cattle production. It was a prairie grassland when the first Spanish explorers arrived, but was modified by planting of trees in windrows and woodlots, and by agricultural practices (Hicks, 1982). A complete phytogeographic study of Pergamino Co. (northern Buenos Aires Province) was conducted by Parodi (1930). At that time the area was already described as principally cultivated plants and weeds. During 1979-1984, 39\% of cultivated land in southern Santa Fe Province was dedicated to soybeans, $38 \%$ to wheat, and $20 \%$ to corn (Instituto Nacional de Tecnología Agropecuaria, 1985). Cultivated fields are crossed by fencelines, dirt roads, and railroads. These linear habitats provide year-round favorable habitat for rodents when agricultural lands are being tilled.

From 1 November 1987-30 February 1988, a field team visited 14 farm sites on a rotational basis, sampling three to four sites/night, 4 nights/week. Thus, each of the 14 sites was visited ca. 1 night/week. During this period, ca. 100 Sherman live traps ( 8 by 9 by $23 \mathrm{~cm}$ ) baited with a mixture of bird seed or rolled oats and peanut butter were placed in traplines of 10-20 traps at 5-m intervals at each farm on the afternoon of each trap day. Traplines were placed in crops and along fencelines, roadsides, and railroads, and were collected early the following morning. Rodents were necropsied. We recorded the following for all animals: date, location and habitat of capture, sex, species, and standard external measurements (lengths of body, tail, right ear, and right hind foot). Traps in which rodents were captured were decontaminated in detergent and water before reuse to prevent cross-contamination or introduction of Junin virus into new areas.

From 1 March to 31 October 1988, the trapping scheme changed in that five farm sites were deleted from the program and four others were substituted. The 13 remaining farm sites were visited on a rotational basis such that each site was visited at 5-week intervals and generally sampled for 3 consecutive nights. During this period, the 100 Sherman traps placed at each farm site per night were supplemented with 30,14 by 14 by $40 \mathrm{~cm}$ Tomahawk live traps baited with peanut butter. Trap success was calculated as number of captures/number of trap-nights $\times 100$. Trap-nights is the number of traps/night $\times$ the number of nights in the field minus one-half of the number of sprung-but-empty traps encountered.

Habitats were divided into three categories: major crops, linear, and other. Major crops included preharvest and postharvest corn, wheat, and soybeans. Harvest dates in the study area were 26 November-11 December 1987 for wheat, 1 April-1 May 1988 for corn, and 9 May-7 June 1988 for soybeans. Linear habitats included the weedy borders, 1-3 $\mathrm{m}$ wide, on either side of fencerows, railroad beds, and roads. The category "other" included windrows (trees), weedy areas near houses and farm buildings, streamside, pasture, and other crops such as sunflowers and lentils.

Vegetation in cultivated fields was dominated by the crop species planted, although the number and contribution of weed species varied among fields. Major weeds encountered in corn and soybeans included Sorghum halapense, Echinochloa crus-galli, Chenopodium album, Datura ferox, Stellaria media, and Amaranthus sp. In wheat, major weed species were S. halapense, Ammi majus, Brassica campestre, Polygonum aviculare, and Bowlesia incana. Linear habitats supported a mixed vegetation dominated by $S$. halapense, C. album, Artemisia sp., Bromus uniloides, Stipa hyalena, Carduus sp., and Eryngium sp. Recorded vegetation height was the mean of five measurements of maximum height of the crop or dominant vegetation in each habitat each time traps were placed. These heights were measured at intervals of ca. 5 
$\mathrm{m}$ along traplines. Trees were present only in rare windrow habitats. Their height was not included in estimates of height of vegetation.

Habitat associations were tested by deriving an expected number of captures of each species in each habitat by multiplying the proportion of trap-nights in a specific habitat by the total number of individuals of each species captured. This expected value was compared to the observed number of captures in a particular habitat and $\chi^{2}$ values for each species derived. Deviations of observed values from expected were standardized as percentages of expected values. Significant deviations from expected associations were tested by the use of $95 \%$ Bonferroni confidence intervals (Byers et al., 1984).

Direct counts of numbers of trapped species (NO; sensu Ludwig and Reynolds, 1988), were used to measure species richness. Hill's (1973) diversity indices N1 and N2 were used to measure "effective numbers" of "abundant" and "very abundant" species, respectively. $N 1=e^{H^{\prime}}$ where $H^{\prime}=$ Shannon's index, $H^{\prime}=-\Sigma\left(p_{i} l n\right.$ $p_{i}$ ), and $N 2=1 / \lambda$, where $\lambda=$ Simpson's index, $\lambda=\Sigma p_{i}{ }^{2}$. In all cases, $p_{i}$ is the proportional abundance of the $i^{\text {th }}$ species. The "effective number" of species is a measure of the number of species in a sample in which each species is weighted by its abundance (Ludwig and Reynolds, 1988). Evenness was measured by the $J^{\prime}$ index of Pielou $(1975)$ where $J^{\prime}=\ln (N 1) / \ln (N 0)=H^{\prime} / \ln (S)$, and $S=$ the total number of species in the community. Also, evenness was indexed by the modified Hill's (1973) ratio N2-1/N1-1, which approaches zero as one species becomes dominant (Ludwig and Reynolds, 1988).

We sampled all of the major habitat categories at each study site, and the same six common species of rodents were present at all sites in similar proportions. Therefore, data on trap success and habitat associations were combined across all study sites for all analyses. Data were analyzed by use of Microsoft Excel (Microsoft Corporation, 1986) and StatView II (Feldman et al., 1987) for the Apple Macintosh.

\section{Results}

The 952-mm rainfall in Pergamino during the study period was close to the 956-mm annual average (based on 80 years of data; Instituto Nacional de Tecnología Agropecuaria, Pergamino, Argentina). The monthly rainfall pattern, however, was aberrant: $40 \%$ of the total fell during March ( $>200 \%$ of normal) and the autumn and winter months (April-October) were dry $(60 \%$ below normal). Mean temperatures, mean minima, and absolute minima for winter months (May-September) were $\geq 2{ }^{\circ} \mathrm{C}$ below the 23 -year means. The absolute minimum $\left(-6.9^{\circ} \mathrm{C}\right)$ for July was the coldest on record ( 23 years, Instituto Nacional de Tecnología Agropecuaria, Pergamino, Argentina). The monthly mean maximum temperatures in the summer months were close to average $\left(27-28^{\circ} \mathrm{C}\right)$ and the absolute maximum for January was $38.0^{\circ} \mathrm{C}$.

The weather pattern during the year preceding the study was unusual. Summer (December 1986-February 1987) was hot and dry: monthly mean maximums were $1.5-2.0^{\circ} \mathrm{C}$ above average and the absolute maximum for January 1987 set a 23-year record (Instituto Nacional de Tecnología Agropecuaria, Pergamino, Argentina). The $12 \mathrm{~mm}$ of rainfall in December 1986 contrasts with an 80-year mean of $103 \mathrm{~mm}$, and rainfall for January 1987 was $14 \%$ below average. Late autumn 1987 was unusually cold: the mean minimum temperature was $3^{\circ} \mathrm{C}$ below average and there were 8 days (compared to a 20-year mode of no days) of subfreezing temperatures. Rainfall during mid-winter (July) was 2.6 times average.

From 1 November 1987 through 31 October 1988, 1,652 mammals were captured during 33,060 trap-nights (5.0\% trap success combining Sherman and Tomahawk traps). Fourteen species were captured, including 10 rodents, 3 marsupials, and 1 mustelid (Table 1). A. azarae was the most commonly caught rodent, comprising $28 \%$ of captures; two species of Calomys comprised $37 \%$; $13 \%$ were B. obscurus; Oligoryzomys flavescens and M. musculus comprised $8 \%$ each of the total captures. These six named species accounted for $>95 \%$ of the total captures and were the major focus of this paper.

Overall trap success for Sherman traps was 5\% (Table 2) with the greatest catch per unit effort (51\% of total captures) in the relatively stable linear habitats. Among crops, trap success was greatest in wheat (10\% of captures) and lowest in soybeans (6\% of captures). Overall success with Tomahawk traps was $1.9 \%$ with most captures being Cavia aperea and Lutreolina crassicaudata from linear habitats. A high success with Tomahawk traps $(4.9 \%)$ was noted in the "other" habitat category, and 10 of these 13 captures were C. aperea from streamside and weedy areas near buildings. No captures in Tomahawk traps were recorded in $>400$ trap-nights in the three crops. 
TABLE 1.-Species captured in Sherman and Tomahawk live traps 1 November 1987-31 October 1988 in northern Buenos Aires and southern Santa Fe provinces, Argentina.

\begin{tabular}{|c|c|c|c|c|}
\hline \multirow[b]{2}{*}{ Species } & \multicolumn{3}{|c|}{ Number of animals captured } & \multirow{2}{*}{$\begin{array}{l}\text { Percent } \\
\text { of totals }\end{array}$} \\
\hline & Sherman & Tomahawk & Totals & \\
\hline Akodon azarae & 462 & & 462 & 28.1 \\
\hline Calomys laucha & 320 & & 320 & 19.5 \\
\hline Calomys musculinus & 287 & & 287 & 17.5 \\
\hline Bolomys obscurus & 217 & & 217 & 13.2 \\
\hline Mus musculus & 139 & & 139 & 8.5 \\
\hline Oligoryzomys flavescens & 136 & & 136 & 8.3 \\
\hline Rattus rattus & 15 & 3 & 18 & 1.1 \\
\hline Rattus norvegicus & 5 & & 5 & 0.3 \\
\hline Cavia aperea & 3 & 23 & 26 & 1.6 \\
\hline Holochilus brasiliensis & & 1 & 1 & $<0.1$ \\
\hline Monodelphis dimidiata & 10 & & 10 & 0.6 \\
\hline Didelphis albiventris & 9 & & 9 & 0.5 \\
\hline Lutreolina crassicaudata & 3 & 8 & 11 & 0.7 \\
\hline Galictis cuja & & 1 & 1 & $<0.1$ \\
\hline Totals & 1,606 & 36 & $1,642^{\mathrm{a}}$ & 100.0 \\
\hline
\end{tabular}

${ }^{2}$ Ten captures not included because species was not recorded.

Trap success in linear and the three major crop habitats accounted for $84 \%$ of all captures and $85 \%$ of the captures of the six rodent species mentioned earlier. For the remainder of this paper, the term "trap success" will refer to trap success in Sherman traps only.

Seven or eight species were recorded from all major crops (Table 3). Linear habitats contributed $70.2 \%$ of the larger mammal species (L. crassicaudata, C. aperea, G. cuja, D. albiventris), and all the L. crassicaudata, C. aperea, and M. dimidiata were captured in this, or in the "other," habitat category. As the "other" category actually was composed of $>15$ relatively rare habitats, computation of its richness, and diversity values is not meaningful. Soybeans and corn had similar measures of abundant $(\mathrm{N} 1)$ and very abundant $(\mathrm{N} 2)$ species, whereas wheat was intermediate between the other crops and linear habitats in these measures. In both indices, there was a gradient of increasing diversity from soybeans to corn to wheat to linear habitats. Soybeans, corn, and linear habitats had comparable evenness scores; the high score for wheat indicated a relatively more even distribution of numbers of individuals among species.

Population density for C. musculinus in all habitats was relatively high in spring and remained so through summer and early autumn (trap success from $0.9-1.8 \%$ in November-April; Fig. 1a). The population declined in late autumn such that trap success was zero by mid-winter, but it recovered rapidly the following spring. Population dynamics of C. laucha followed a similar pattern (Fig. 1a), with relatively high densities in summer and autumn $(0.8-2.6 \%$ in DecemberApril), decreasing to near zero trap success in winter and recovering in spring. The M. musculus population also showed a high relative density in summer and early autumn $(0.6-0.9 \%$ from November-March) with a sharp decline in later autumn and winter (Fig. 1a), but recovery the following spring was poor as of October. In contrast, Akodon, Bolomys, and Oligoryzomys all

TABLE 2.-Total trap success in Sherman traps by habitat in northern Buenos Aires and southern Santa Fe provinces, Argentina, 1 November 1987-31 October 1988.

\begin{tabular}{lrcc}
\hline Habitat & Trap-nights & $n$ & Trap success (\%) \\
\hline Soybeans & $5,560.5$ & 103 & 1.9 \\
Corn & $6,591.5$ & 281 & 4.3 \\
Wheat & $3,053.5$ & 158 & 5.2 \\
Linear $^{\mathrm{a}}$ & $10,811.5$ & 823 & 7.6 \\
Other $^{\mathrm{b}}$ & $5,177.5$ & 248 & 4.8 \\
Totals & $31,194.5$ & $1,613^{\mathrm{c}}$ & 5.2 \\
\hline
\end{tabular}

ancludes railroads, fencerows, and roadsides.
b Includes windrows (trees), weedy areas near houses or farm buildings, streamsides, pastures, and relatively rare crops such as sunflowers.

c Three captures not included because habitat is unknown. 
TABLE 3.-Species richness, diversity, and evenness for mammals captured in different habitats in northern Buenos Aires and southern Santa Fe provinces, Argentina, 1 November 1987-31 October 1988.

\begin{tabular}{|c|c|c|c|c|c|}
\hline \multirow[b]{2}{*}{ Habitat } & \multicolumn{3}{|c|}{ Hill's diversity index $x^{a}$} & \multicolumn{2}{|c|}{ Evenness index } \\
\hline & $N O^{b}$ & $N 1$ & N2 & 1 & 5 \\
\hline Soybeans & 7 & 4.26 & 3.24 & 0.74 & 0.69 \\
\hline Corn & 8 & 4.30 & 3.55 & 0.70 & 0.77 \\
\hline Wheat & 7 & 5.03 & 4.46 & 0.83 & 0.86 \\
\hline Linear $^{c}$ & 12 & 5.89 & 4.50 & 0.71 & 0.72 \\
\hline
\end{tabular}

Following Ludwig and Reynolds (1988).

${ }^{b}$ A measure of species richness.

' Includes windrows (trees), weedy areas near houses or farm buildings, streamsides, pastures, and relatively rare crops such as sunflowers.

showed relatively low densities in spring and summer, but a population peak in late autumn and early winter (April-June; Fig. 1b). Although their densities declined in mid- or late winter, trap success did not decrease to near zero as in Calomys and Mus.

Total trap success of all species combined closely followed the growth of the crop plants, as measured by maximum height (Fig. 2). Populations grew rapidly as crops matured, then decreased abruptly following harvest. Few or no animals were found in soybeans and wheat following harvest, although some were captured in postharvest corn. Trap success in linear habitats was relatively stable throughout the year, but increased with vegetation height in spring and declined as vegetation height decreased in winter.

Throughout the year, $50 \%$ of captures in soybeans were C. laucha (Fig. 2a). Wheat was used most heavily by C. musculinus and C. laucha ( $60 \%$ of total captures), but this habitat also supported a large number of Mus and Akodon during November and December (Fig. 2b). Corn was dominated by C. musculinus and C. laucha (70\% of total captures), but captures/trap-night of Akodon increased in March and April just before harvest (Fig. 2c). Mus was relatively rare in corn when compared to that in other crop species. B. obscurus and O. flavescens were almost absent from cultivated habitats ( 4.8 and $2.0 \%$ of captures, respectively). In comparison to crops, capture success in linear habitats was higher for Akodon, Bolomys, and Oligoryzomys (40, 22, and $13 \%$ of captures, respectively), whereas C. musculinus, C. laucha, and Mus were relatively rare $(12,8$, and $5 \%$ of captures, respectively).

Each of the six species of rodents showed a significant degree of heterogeneity in habitat associations: C. musculinus, $\chi^{2}=55.5, P<0.001$; C. laucha, $\chi^{2}=60.7, P<0.001 ; M$. musculus, $\chi^{2}=16.6, P<0.01 ;$ A. azarae, $\chi^{2}=252.8, P<0.001 ; B$. obscurus, $\chi^{2}=217.8, P<0.001 ; O$. flavescens, $\chi^{2}=120.1, P<0.001$.

Trap success for C. musculinus was $78 \%$ greater than expected in wheat $(P<0.05$ for this and all significant deviations from expected captures) and $38 \%$ greater than expected in corn (not significant) during the period that these crops were available. However, this species was significantly underrepresented (78\%) in soybeans even after the corn was harvested (Fig. 2). Linear habitats were used by C. musculinus throughout the year; captures were not significantly less than expected in this habitat.

Calomys laucha was significantly overrepresented in corn (70\%) and wheat $(44 \%)$, but was not significantly (9\%) underrepresented in soybeans. Linear habitats were used to a lesser extent than by C. musculinus, and captures were significantly (41\%) less than expected in this habitat.

Similar to both species of Calomys, Mus primarily was captured in corn and wheat during November and December (Fig. 2). Although statistical tests were not significant because of a relatively small sample, Mus was captured $62 \%$ more frequently than expected in wheat and $52 \%$ more than expected in the "other" habitat category (especially in or near farm buildings). Akodon, Bolomys, and Oligoryzomys were significantly associated with linear habitats throughout the year $(97,137$, and $123 \%$ overrepresented, respectively). These three species were consistently, and significantly, underrepresented in the three crops, with one exception: $O$. flavescens was not significantly (47\%) underrepresented in wheat. 


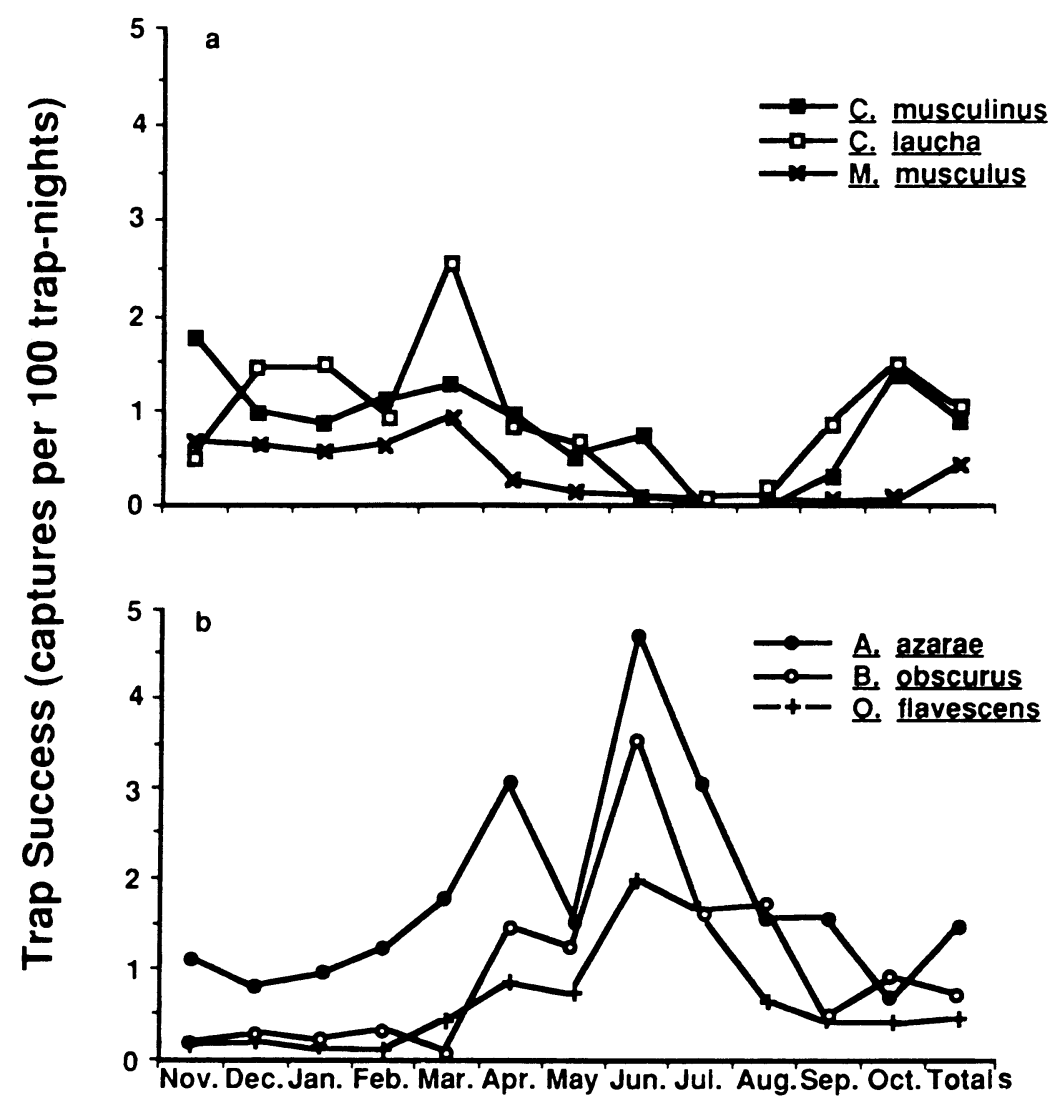

Fig. 1.-Trap success in all habitats combined for: a, Calomys musculinus, C. laucha, and Mus musculus and b, Akodon azarae, Bolomys obscurus, and Oligoryzomys flavescens in Sherman traps, Buenos Aires and Santa Fe provinces, Argentina, 1 November 1987-31 October 1988.

\section{Discussion}

Two distinct patterns in temporal and spatial population fluctuations were apparent for rodents in cultivated regions of the pampas. The first pattern was shared by the two species of Calomys and Mus, which maintained relatively stable populations during most of the year (OctoberMay). This group suffered a precipitous drop in population numbers during winter. In contrast, populations of Akodon, Bolomys, and Oligoryzomys increased during June, and trap-success functions were the approximate inverse of the first group (Fig. 1). These two groups of rodents also showed significant differences in habitat use. Bolomys obscurus, A. azarae, and $O$. flavescens were captured predominantly in linear habitats. In contrast, C. musculinus, C. laucha, and $M$. musculus made extensive use of cultivated fields.

These two patterns in population dynamics and habitat use may reflect relative colonizing potential. Bolomys, Akodon, and Oligoryzomys are relatively successful competitors largely limited to stable habitats (de Villafañe et al., 1977; Kravetz, 1977; Zuleta, 1989). Conversely, Calomys and Mus are able to take advantage quickly of unstable, temporarily suitable habitat for their rapid reproduction (de Villafañe et al., 1977; Kravetz, 1977, 1978; Kravetz et al., 1981). This suitable habitat in the case of summer crops is available throughout the reproductive period of these species, although their populations may be reduced drastically when the habitat is destroyed with crop harvest. Thus, the development of the pampas for agriculture has resulted in the creation of ideal conditions for the expansion of opportunistic species, including the primary 


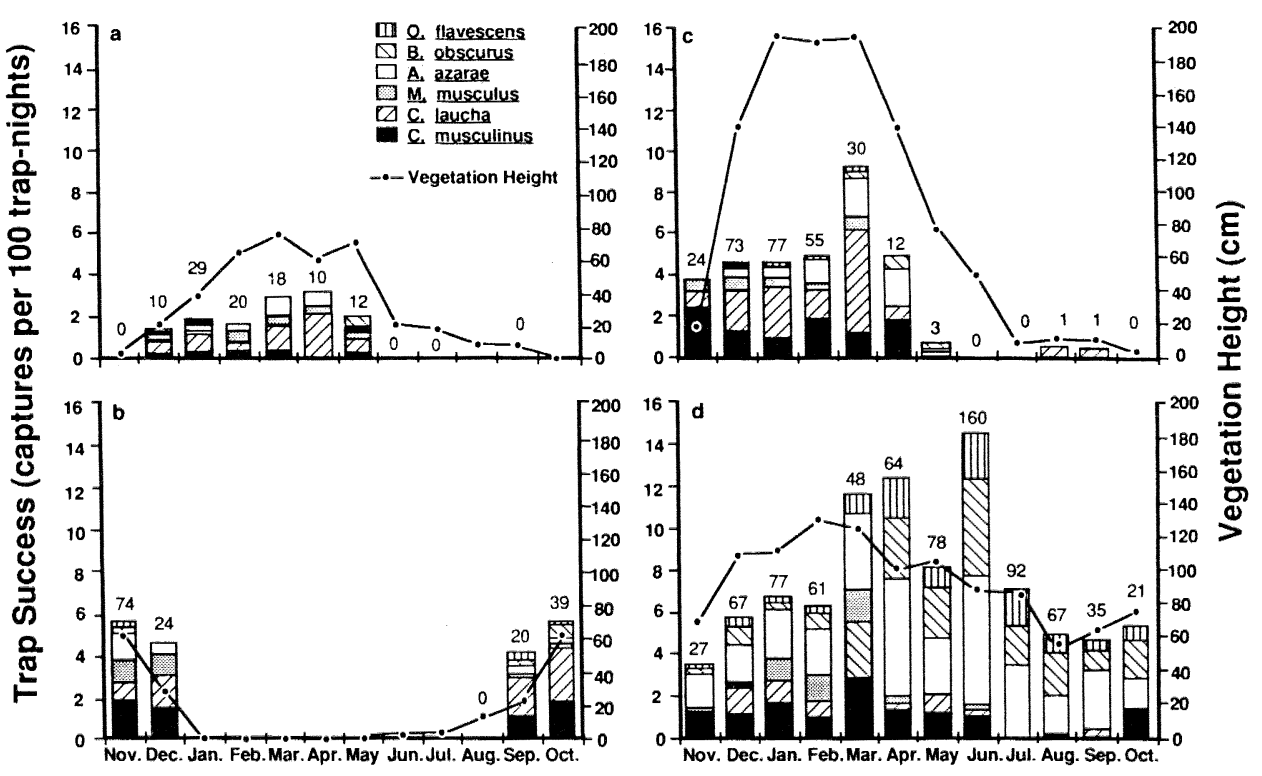

Fig. 2.-Trap success in Sherman traps by species (bars) and mean maximum vegetation height (solid line) in: a, soybeans; b, wheat; c, corn; and d, linear habitats (fencerows, roadsides, and railroads), Buenos Aires and Santa Fe provinces, Argentina, 1 November 1987-31 October 1988. Zeros represent months when no animals were captured and absence of a number indicates months when habitat was not sampled.

reservoir of Argentine hemorrhagic fever (Calomys sp.-Sabattini and Contigiani, 1982; Sabattini et al., 1977), and provided for the exposure of man to infected rodents during harvest, the time of their peak density.

Population peaks of rodents in pampas ecosystems vary considerably from year to year as illustrated by the 3-year study by Crespo et al. (1970). Rhythmic population cycles similar to those found in some microtines are not known for South American cricetines (Dalby, 1975; Pearson, 1967). However, periodic irruptions were reported in central Argentina for the years 1833, 1873, 1944, 1963-1964, 1967, 1974, and 1977 (Carballal et al., 1988; Crespo, 1945, 1966). Irruptions may be followed by years with low population densities, and the periodicity and causes for these peaks and valleys in mean densities of rodents was described by Crespo (1966) as complex and unknown.

Overall and peak trap success for the current study were among the lowest reported. We observed a peak trap success during 1988 of $9.4 \%$ in corn, $5.8 \%$ in wheat, $3.1 \%$ in soybeans and $14.5 \%$ in linear habitats. In contrast, other investigators found 14.0 (de Villafañe et al., 1988) to 35.7\% (Busch et al., 1984) in corn; $11.4 \%$ in soybeans (Busch et al., 1984); $17.2 \%$ in wheat (Busch et al., 1984); and 22.5 (Crespo et al., 1970) to $77.0 \%$ (Crespo, 1966) in linear habitats. Only the trap success of Lord et al. (1971; $13.1 \%$ in linear and $2.5 \%$ in corn) and the 3rd-year of the study by Crespo et al. (1970; $10 \%$ in linear) had values similar to or less than those of our study. The strikingly low trap success seen by Lord et al. (1971) in corn was interpreted by some to indicate deficiencies in the sampling system (de Villafañe et al., 1977). We believe the lower capture success in our study reflected lower densities of rodents during 1987-1988 as compared to that of periods covered by previous studies.

Climatic conditions most unfavorable for rodent populations on the pampas are hot, dry summers, which result in decreased food supply and poorer habitat quality; and cold, wet winters, which cause mortality from exposure (Crespo, 1945, 1966; de Villafañe and Bonaventura, 1987). The weather pattern for the year preceding our study had exactly these characteristics and these unfavorable conditions probably contributed to the low densities of rodents observed during our study. 
In addition to weather, the seasonal dynamics of rodent populations in this region also were influenced profoundly by anthropogenic alterations of the habitat. In each major crop, relative population density for all species of rodents decreased dramatically after harvest (Fig. 2). Capture success in postharvest corn and postharvest soybeans was zero or nearly so. Other investigators (de Villafañe et al., 1988) found only a small decrease in relative densities immediately after corn harvest and continued to have good trap success ( $>8 \%$ ) in postharvest corn for 2 months (through early June). In our study, trap success in all habitats declined during the month of May (even in the undisturbed linear habitat). Thus, the abrupt, postharvest decrease in relative densities probably was the result of extreme weather combined with destruction of habitat and accompanying exposure to greater predation (de Villfañe et al., 1988).

Harvest may have a lesser effect on C. laucha than on C. musculinus, perhaps because the latter species nests on the surface, whereas the former constructs its nests in relatively moreprotected burrows (de Villafañe et al., 1988). However, no evidence for prolonged postharvest survivorship of C. laucha was seen in our study.

Our findings of higher relative densities of rodents in linear habitats compared to those in cultivated fields is in agreement with previous results (Lord et al., 1971). This would support the hypothesis that overall rodent density could be reduced greatly by concentrating control measures on linear habitats (Lord et al., 1971; Maiztegui and Vilches, 1970). However, the impact of such a strategy on human Argentine hemorrhagic fever is questionable because the principal carriers of Junin virus (Calomys sp.) inhabit crop fields. In addition, Akodon and Bolomys are behaviorally dominant over Calomys sp. and may exclude them from linear habitats (de Villafañe et al., 1973, 1977; Kravetz, 1977). Recognizing this pattern of habitat use and social dominance, de Villafañe et al. (1977) and Kravetz (1977) predicted that improving and maintaining stable linear habitats to encourage growth of the dominant species would reduce the populations of Calomys. Our data do not provide a definitive test of this prediction. However, the fact that $C$. musculinus was not captured less frequently than expected in linear habitats argues against competitive exclusion of $C$. musculinus from these habitats during our study.

Although composition of species appears similar, distinctions can be made among the rodent communities of summer crops on the basis of overall densities. We found a three-fold greater trap success in corn than in soybeans, and all rodent species were captured in numbers less than expected in soybeans. These results are in agreement with findings of Busch et al. (1984). We found no evidence for distinguishing between a summer-crop community dominated by Calomys sp. and a winter-crop (wheat) community dominated by Mus (Kravetz, 1977). Undisturbed pasture was poorly sampled in the current study, but it was shown to support a community similar to that in linear habitats (Kravetz, 1977). This Akodon-Bolomys-Oligoryzomys-dominated community may be most typical of the original rodent community that existed before complete alteration of the habitat by humans (de Villafañe et al., 1977).

\section{ACKNOWLEDGMENTS}

This research was supported by a subcontract to Johns Hopkins University from the Pan American Health Organization on grant 17-87-C-7013 from the United States Army Medical Research and Development Command. We also gratefully acknowledge the support and assistance provided JNM by the Health and Child Survival Fellows Program of Johns Hopkins University. Rodents were collected and processed by $\mathbf{H}$. Lopez, A. Fernandez, D. Olivera, J. Ramirez, C. Carpignoli, M. Cangiaso, and J. L. Becker. J. M. Tardivo provided us with logistical support. M. Piantanida confirmed our identification of rodent species, and B. Echeverria confirmed identification of plants. G. Nelson provided statistical advice and analyses. G. Glass and two anonymous reviewers made valuable comments on earlier versions of this manuscript. Special thanks are due the professionals and technicians of the Instituto Nacional de Estudios sobre Virosis Hemorrágicas, Pergamino, Argentina, for their active support of our research.

\section{Literature Cited}

Busch, M., F. O. Kravetz, R. E. Percich, and G. A. Zuleta. 1984. Propuestas para un control ecológico de la Fiebre Hemorrágica Argentina $a$ través del manejo del hábitat. Medicina (Buenos Aires), 44:34-40.

Byers, C. R., R. K. Steinhorst, and P. R. Krausman. 
1984. Clarification of a technique for analysis of utilization-availability data. The Journal of Wildlife Management, 48:1050-1053.

$\rightarrow$ Carballal, G., C. M. Videla, and M. S. Merani. 1988. Epidemiology of Argentine hemorrhagic fever. European Journal of Epidemiology, 4:259274.

Crespo, J. A. 1945. Relaciones entre estados climáticos y la ecología de algunos roedores del campo (Cricetidae). Revista Argentina Zoogeográfica (Buenos Aires), 41:137-144.

- 1966. Ecología de una comunidad de roedores silvestres en el Partido de Rojas, provincia de Buenos Aires. Revista del Museo Argentina de Ciencias Naturales "Bernadino Rivadavia" e Instituto Nacional de Investigación de las Ciencias Naturales, Ecología (Buenos Aires), 1:79-144.

Crespo, J. R., M. S. Sabattini, M. J. Piantanida, and G. DE VILLAFAÑE. 1970. Estudios ecológicos sobre roedores silvestres. Observaciones sobre densidad, reproducción y estructura de comunidades de roedores silvestres en el sur de la provincia de Córdoba. Ministerio de Bienestar Social, Secretaria de Estado de Salud Pública, Buenos Aires, Argentina, $45 \mathrm{pp}$.

DALBY, P. L. 1975. Biology of pampa rodents (Balcarce area, Argentina). Publications of The Museum, Michigan State University, Biological Series, 5:149-272.

de Villafañe, G., and S. M. Bonaventura. 1987. Ecological studies in crop fields of the endemic area of Argentine hemorrhagic fever. Calomys musculinus movements in relation to habitat and abundance. Mammalia, 51:233-248.

de Villafañe, G., S. M. Bonaventura, M. I. Belloce, AND R. E. PERCICH. 1988. Habitat selection, social structure, density and predation in populations of cricetine rodents in the Pampa region of Argentina and the effects of agricultural practices on them. Mammalia, 52:339-359.

de Villafañe, G., F. O. Kravetz, M. J. Piantanida, and J. A. Crespo. 1973. Dominancia, densidad e invasión en una comunidad de roedores de la localidad de Pergamino (provincia de Buenos Aires). Physis, Sección C (Buenos Aires), 32:47-59.

de Villafañe, G., et al. 1977. Dinamica de las comunidades de roedores en agroecosistemas pampasicos. Medicina (Buenos Aires), 37, suppl. 3:128140.

Feldman, D. S., J. Gagnon, R. Hofmann, and J. SimPSON. 1987. StatView II. Version 1.03 manual. Abacus Concepts, Inc., Berkeley, California, 278 pp.

HICKs, D. R. 1982. Agronomic characterization of the Argentina indicator region. National Aeronautics and Space Administration Technical Report, SR-E2-04222:1-135.

HiLl, M. O. 1973. Diversity and evenness: a unifying notation and its consequences. Ecology, 54: 427-432.

Instituto de Virología de Córdoba. 1966. Virus Junin en la provincia de Córdoba. Pp. 85-102, in Comisión Nacional Coordinadora Para Estudio y Lucha Contra Fiebre Hemorrágica Argentina.
(Contribuciones de los organismos integrantes). Secretaria de Estado de Salud Pública, Buenos Aires, Argentina, $102 \mathrm{pp}$.

Instituto NaCional de TeCNOLOGía Agropecuaria. 1985. Aspectos ecológicos, productivos, económicos, sociales y tecnológicos del sector agropecuario de la provincia de Santa Fe. Plan de Acción Centro Regional Santa Fe, Rafaela, provincia de Santa Fe, Argentina, $98 \mathrm{pp}$.

KravetZ, F. O. 1977. Ecología y control de reservorios. Ciencia e Investigación (Argentina), 33:235242.

- 1978. Ecología de las comunidades de roedores involucrados en la fiebre hemorrágica Argentina. Ph.D. dissert., University of Buenos Aires, Buenos Aires, Argentina, 193 pp.

Kravetz, F. O., G. De Villafañe, M. P. Torres, and M. J. Piantanida. 1975. Poblaciones de roedores en un campo de trigo. Physis (Buenos Aires), 31: 187-197.

Kravetz, F. O., M. C. Manjon, M. E. Busch, R. E Percich, P. Marconi, and M. P. Torres. 1981. Ecología de Calomys laucha (Rodentia, Cricetidae) en el departamento de Río Cuarto (Córdoba). I. Dinámica de población. Ecología (Argentina), 6:15-22.

Lord, R. D., A. M. Vilches, J. I. Maiztegui, E. C. Hall, and C. A. Soldini. 1971. Frequency of rodents in habitats near Pergamino, Argentina, as related to Junin virus. The American Journal of Tropical Medicine and Hygiene, 20:338-342.

LudwiG, J. A., AND J. F. Reynolds. 1988. Statistical ecology. John Wiley \& Sons Inc., New York, 337 pp.

Maiztegui, J. I., AND A. M. Vilches. 1970. Estudio experimental sobre control de roedores del area rural: contribución a la prevención de la fiebre hemorrágica Argentina. Medicina (Buenos Aires), 30:39.

Maiztegui, J. I., M. Feuillade, and A. Briggilier. 1986. Progressive extension of the endemic area and changing incidence of Argentine hemorrhagic fever. Medical Microbiology and Immunology, 175: 149-152.

Microsoft Corporation. 1986. Microsoft Excel user's guide. Version 1.06 manual. Redmond, Washington, $364 \mathrm{pp}$. (on disk).

Parodi, L. R. 1930. Ensayo fitogeográfico sobre el Partido de Pergamino. Estudio de la pradera pampeana en el norte de la provincia de Buenos Aires. Revista de la Facultad de Agronomía y Veterinaria (Argentina), 7:65-271.

Pearson, O. P. 1967. La estructura por edades y la dinámica reproductiva en una población de ratones del campo, Akodon azarae. Physis (Buenos Aires), 27:53-58.

Pielou, E. C. 1975. Ecological diversity. John Wiley \& Sons Inc., New York, 165 pp.

Polop, J. J., C. N. Gardenal, and M. S. Sabattini. 1982. Comunidades de roedores de cultivos de sorgo en la provincia de Córdoba y su posible vinculación con la fiebre hemorrágica Argentina. Ecosur (Argentina), 9:107-116.

Sabattini, M. S., and M. S. Contigiani. 1982. Pp. 
251-262, in Ecological factors influencing the maintenance of arenaviruses in nature with special reference to the agent of Argentinean haemorrhagic fever (F. de P. Pinhiero, ed.). Academia Brasilera de Ciencias, Rio de Janeiro, 262 pp.

Sabattini, M. S., and J. I. Maiztegui. 1970. Fiebre hemorrágica Argentina. Medicina (Buenos Aires), 30:111-128.

Submitted 9 November 1989, Accepted 9 July 1990.
Sabattini, M. S., L. E. Gonzalez de Rios, G. Diaz, AND V. R. VEGA. 1977. Infección natural y experimental de roedores con virus Junin. Medicina (Buenos Aires), 37, suppl. 3:149-161.

Zuleta, G. A. 1989. Estrategias de historia de vida en el ratón del pastizal pampeano, Akodon azarae. Ph.D. dissert., University of Buenos Aires, Buenos Aires, Argentina, 161 pp. 